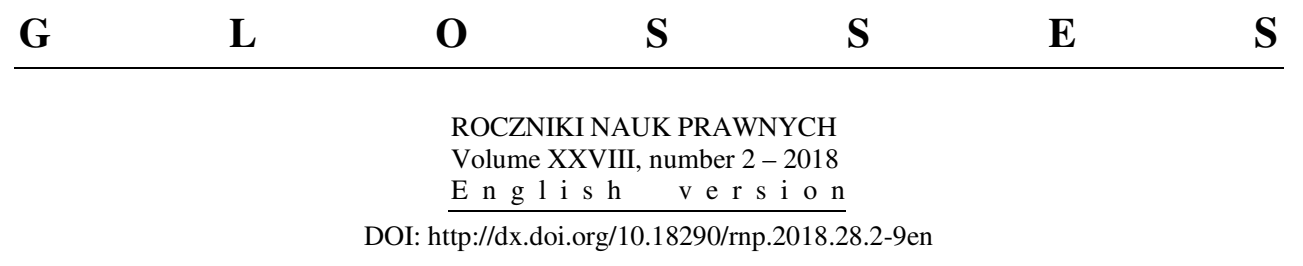

GRZEGORZ WOLAK

\title{
A GLOSS TO THE DECISION OF THE SUPREME COURT OF 16 OCTOBER 2014, FILE REF. NO. III CSK 301/13
}

\section{PROPOSITION}

In principle, a member of the governing body of a legal entity is allowed to witness the making of a last will, which provides for a certain benefit for that entity. Similarly, in principle, a member of a corporate legal entity for which a benefit is envisaged by a will may witness the making of it. ${ }^{1}$

\section{INTRODUCTION}

The glossed decision of the Supreme Court of October 16, 2014, file ref. no. III CSK $301 / 13^{2}$ was issued in the case involving an ascertainment of acquisition of inheritance. The Supreme Court dismissed as unfounded the appeal in cassation brought by the petitioner B.W. against the decision of the Regional Court in N. of May 22, 2013, which dismissed her appeal against the decision of the Court of first instance, stating that the estate of the deceased L.S. on the basis of an oral will under Article 952 of the Polish Civil

GrZegorz WolaK, PhD, is an assistant professor at the Department of Private Law, Institute of Law and Economy, Off-Campus Faculty of Law and Social Sciences of the John Paul II Catholic University of Lublin (KUL) in Stalowa Wola; address: ul. Ofiar Katynia 6a, 37-450 Stalowa Wola, Poland; e-mail: wolaczek@kul.pl

${ }^{1}$ This decision is without a proposition. The proposition presented in the gloss is formulated by its author.

${ }^{2}$ OSP [Decisions of Polish Courts] of 2015, no. 12, item 117, pp. 1727-30, LEX no. 1598693. 
Code $^{3}$ is inherited by the Gmina of $\mathrm{U}^{4}$ The Supreme Court found, among other things, that: "A member of the governing body of a legal person may in principle witness the drafting of a will in which any benefit is foreseen for that person. Similarly, in principle, a member of a corporate legal entity for whom the will provides for a benefit may witness the drafting of it."

While the dismissal of the appeal in cassation was, in my opinion, in itself valid and in line with substantive and procedural law, the view expressed in this decision regarding the possibility for an office holder of the governing body to witness a will which provides for a benefit of a legal person or its member (shareholder), should not be approved. I share the criticism expressed in the literature by Katarzyna Duszynska-Misarko and Paweł Księżak ${ }^{5}$ and Michał Niedośpiał in this regard. ${ }^{6}$ I believe that it is right to take an opposing view to the one presented in this judgement, namely that: "A witness at the drawing up of a will providing for any benefit to a legal person shall not, in principle, be an officer of the governing body of such a legal person or any member (shareholder) of a corporate legal entity."

\section{FACTS OF THE CASE}

The testator L.S. died on June 20, 2010 in G. She had been married twice. Her child from her first marriage is the applicant B.W. The testator had no other children, and at the time of her death she was divorced. From June 2, 2010 until her death she was hospitalised in G. with a suspicion of cancer. On June 13, 2010, she was in a generally severe condition. On June 16, 2010, her condition deteriorated and became very severe, and on June 19, 2010 her state became critical. Since her admission, the testator was not ambulatory on her own, she felt weak and was unable to write. A few days before June 13, 2010, she sold her car and transferred the money from the sale to M.P. for paying her bills. Back in May 2004, L.S. had drawn up a document which included a statement that she would bequeath all her assets to

\footnotetext{
${ }^{3}$ Journal of Laws of 2017, items 459, 933, 1132 [henceforth abbreviated as CC].

${ }^{4}$ [Gmina is an administrative unit similar to a municipality-Translator's note] When the case was originally examined, the assumption was made that the estate would be inherited by the applicant B.W. in its entirety on the basis of the statutory law.

${ }^{5}$ K. DUSZYŃSKA-MISARKO and P. KSIĘŻAK, Glosa do postanowienia SN z dnia 16 października 2014 r., III CSK 301/13, OSP of 2015, no. 12, item 117, pp. 1730-35.

${ }^{6}$ M. NiEdoŚPIAe, "Glosa do postanowienia SN z dnia 16 października 2014 r., III CSK 301/ 13," Palestra 4 (2017): 100-108.
} 
a foundation supporting people with disabilities in S. on condition that the facility would take care of her. On June 13, 2010, the testator asked M.P., the sołtys [village head-Translator's note] of W. to submit that document to the hospital. On June 13, 2010, the testator was visited by Z.F. and his son M.F. in the hospital. On the same day, L.S. asked M.P. and his wife J.P. to bring her the 2004 will. L.S. wanted to edit it by naming the Gmina of U. and excluding the Foundation. However, she had no strength to do that. She asked her visitors if they would witness her will and they agreed. The testator declared in their presence that she was bequeathing all her property to the Commune of $\mathrm{U}$. for the care provided to her before and during her illness. She also stated that she was disinheriting her daughter and sons. On June 13, 2010, the testator was sane and had the ability to bequeath. On November 7, 2010, a record of the will was drawn up by M.P. and subsequently signed by J.P., Z.F. and M.F.

\section{POSITION OF THE COURTS}

Having re-examined the case, the District Court in G., by its decision issued on January 10, 2013, stated that the estate of L.S. on the basis of the oral will of June 13, 2010, made in the hospital in G., in the presence of witnesses J.P, M.P., Z.F. and M.F., was acquired with the benefit of inventory by Gmina of U. The court did not recognise the last will and testament of May 2004 as valid, since the testator, while disposing of her estate in case of her death, included a condition clause which under Article $962 \mathrm{CC}$ is unacceptable. It stated that the succession was based on the will of June 13, 2010 made in the presence of four witnesses who were aware of their role, none of whom, according to Article $957 \S 1 \mathrm{CC}$, was exempted as a witness. In particular, M.P. was not subject to such an exclusion due to his function as the village head of $\mathrm{W}$. It cannot be assumed that since the benefit was attributed to the Gmina of U., it was also indirectly attributed to the village of W. located within this Gmina. In addition, M.P. was admitted to the will as a private person. The court also reasoned that the testator was in fear of imminent death. Moreover, her state of health prevented her from making a will in a different form as she was unable to write or see a notary. There was no doubt as to the testator's awareness of her actions on the date of the oral will, which was confirmed by an expert opinion.

The Regional Court in N., agreed with this assessment and dismissed the applicant's appeal. The Court did accept the claim that the testator's declaration 
of the will of June 13, 2010 did not constitute a last will and testament as it was made subject to a condition. The Court stressed that, although the letter declaring the oral will made reference to the testator's document of May 2004, it could not be said, however, that it stipulated a condition. The testator's statement that "all her estate is hereby bequeathed to Gmina of U. in exchange for care and payment for her stay in a nursery home" should be construed as an expression of the testator's gratitude for placing her in that facility rather than a condition. The Regional Court also decided that there was a fear of imminent death, as evidenced by the type and number of diseases she had been diagnosed with, as well as the manner of their treatment. The Court rejected the allegation that M.P., as the soltys of W., could not witness the will because he was not the governing body of the Gmina.

Finally, the Supreme Court dismissed the applicant's appeal in cassation as groundless based on charges of substantive law infringements, namely Article $957 \S 1$, Article $952 \S 1$ and Article $948 \S 1$ in relation to Article 962 CC.

\section{ASSESSMENT OF THE SUPREME COURT'S POSITION}

In the presented gloss, I shall address the complaint in cassation based on an infringement of Article $952 \S 1 \mathrm{CC}$ (suffice it to say that the testator L.S. made an oral will a week before her death, when she was in a serious condition due to a suspicion of progressing cancer, unable to walk or write; a few days later her condition became critical; it is then obvious to me that the said article was not offended by the courts).

First of all, I would like to focus on the question whether Article $957 \mathrm{CC}$ was infringed. According to Article $957 \S 1 \mathrm{CC}$, an individual for whom any benefit is envisaged in the will cannot be a witness to the making of a will. Neither can the following act as witnesses: the spouse, relatives by consanguinity or affinity or in the first and second degree and individuals having an adoption relationship with the testator. Pursuant to $\S 2$, if one of these persons was a witness, only the decision that benefits the person, the spouse, relatives by consanguinity or affinity of the first or second degree or a person in the adoption relationship with the testator, the will shall be invalid. However, if it is clear from the content of the will or from the circumstances that, without the invalid provision, the testator would not have drawn up a will for the content in question, the entire will is invalid.

This provision is intended to limit the ability to act as a witness to the making, for example of an noncupative will by public act (Article $951 \mathrm{CC}$ ) 
and an oral will (Article $952 \mathrm{CC}$ ) by certain categories of entities. This is mainly due to the purpose of the institution of witness to a will. As Joanna Haberko aptly points out, a witness to a will is to be, according to the legislator's intention, an impartial observer and an impartial source of information regarding the testator's declaration of will. This assumption is not met by a witness who remains interested in the decision itself, similar to a witness whose family member might be interested in the decision in the form of a given testamentary disposition. The legislator, probably guided by life experience, assumes that people, including witnesses to a will, would be willing to show a greater loyalty to living family members than to the deceased testator, even at the expense of truthfulness of the statements they make. Moreover, the legislator excludes the need to resolve ad hoc dilemmas regarding the admissibility or inadmissibility of witnessing by individuals close to the person for whom a benefit is provided for in the will. In this respect, it is determined by the formal criterion which is a family-law relationship. ${ }^{7}$ The author also points out, not without reason, that in view of the changing realities of family life, de lege ferenda it is necessary to broaden the catalogue of persons with whom the heir or legatee would remain in a close relationship, namely a cohabiting person. Under the existing law, a cohabiting partner of a person for whom the testator provided for a benefit can be a witness to the will, regardless of the nature of that relationship (e.g. a homosexual partner). ${ }^{8}$

The benefit referred to in Art 957 \& $1 \mathrm{CC}$ may consist in making one eligible to inherit the whole or a fractional part of the inheritance (regardless of the inheritance debt), even if only by way of substitution (Article $963 \mathrm{CC}$ ), or in establishing a legatee (ordinary or under debt collection). This also applies to an order which imposes an obligation on the heir or legatee to proved a specific increment to benefit a witness or a person having a relationship with him as defined by Article $957 \mathrm{CC}$, although these persons do not acquire the status of creditors as a result of such an order. ${ }^{9}$ It is not

\footnotetext{
${ }^{7}$ Cf. J. Haberko, "Komentarz do art. 957 k.c.," in Kodeks cywilny. Tom II. Komentarz. Art. 450 1088, ed. M. Gutowski (Warszawa: Wydawnictwo C.H. Beck, 2016), Legalis, point I, sub-point 1.

${ }^{8}$ Ibid.

${ }^{9}$ Similarly in J. HABerko, "Komentarz do art. 957 k.c.," in Kodeks Cywilny. Tom II. Komentarz. Art. 455-1088. Przepisy wprowadzające, ed. K. Pietrzykowski (Warszawa: Wydawnictwo C.H. Beck, 2013), 864; L. STECKI, "Komentarz do art. 957 k.c.," in Kodeks cywilny z komentarzem, ed. J. Winiarz (Warszawa: Wydawnictwo Prawnicze, 1980), 857; S. WóJCIK and F. ZoLL, "Rozdział IV. Testament," in Prawo spadkowe, ed. B. Kordasiewicz, vol. 10 of System Prawa Prywatnego (Warszawa: Wydawnictwo C.H. Beck, 2015), 397; HABERKO, Komentarz do art. 957 k.c., point I, sub-point 2. A different position is presented in F. BŁAHUTA, "Komentarz do art. 957
} 
a benefit, within the meaning of Article $957 \mathrm{CC}$, to be appointed executor of a will. ${ }^{10}$

It is quite obvious that only a natural person can be a witness to a will. This transpires indirectly from the indications of absolute incapacity to witness under Article $956 \mathrm{CC}$, which by their nature cannot apply to legal persons. In this article it is provided, however, that the following cannot witness the making of a will: 1) an individual who does not have full legal capacity for legal acts; 2) blind, deaf or silent person; 3) one who cannot read and write; 4) an individual who does not speak the language in which the will is made; or 5) a person convicted of perjury by a final judgement.

In the introduction to the reasons, the Supreme Court asked whether Article $957 \mathrm{CC}$, which regulates relative incapacity to witness, may apply by analogy where a benefit for a legal entity is provided for in a will. The Court referred to its order of May 7, 1976, file ref. no. III CRN 9/76 ${ }^{11}$ which expressed the view that: "The restriction introduced by Article $957 \S 1 \mathrm{CC}$ that a person for whom any benefit is envisaged in a will may not be a witness to the making of a will does not refer to members of the governing body of legal persons." In the opinion of the Supreme Court expressed in the decision at hand, this view should be in principle accepted, despite the fact that a different interpretation is predominant in the literature.

The operation of governing bodies of legal persons is-according to the so-called theory of governing bodies (Article $38 \mathrm{CC}$ ) - is an operation of a legal person. In order for legal persons to be party to legal transactions, the existence of at least one body is required. Actions of natural persons constituting the organ of a legal person is an act of that legal person if those persons act as an organ within the scope of their competence; the will of the natural persons constituting the governing body of a legal person is their will from a psychological point of view, whereas in the legal sense it is a will of the legal person. ${ }^{12}$ At first glance it would seem legitimate to assume that an office holder of the governing body of a legal entity cannot witness a will in

k.c.," in Kodeks cywilny. Komentarz (Warszawa: Wydawnictwo Prawnicze, 1972), 3: 1884; J. KREMIS, "Komentarz do art. 957 k.c.," in Kodeks cywilny. Komentarz, ed. E. Gniewek and P. Machnikowski (Warszawa: Wydawnictwo C.H. Beck, 2013), 1631.

${ }^{10}$ As interpreted by PAZDAN, "Komentarz do art. 957 k.c.," 864; BŁAHUTA, "Komentarz do art. 957 k.c.," 1884; KREMIS, "Komentarz do art. 957 k.c.," 1631. For a different view in this regard, see WóJCIK and ZoLl, "Rozdział IV. Testament," 397.

${ }^{11}$ Unpublished.

${ }^{12}$ See for example A. KawaŁko and H. Witczak, "Rozdział IV. Podmioty prawa cywilnego, $\S$ 13. Osoby prawne," in Prawo cywilne-część ogólna (Warszawa: Wydawnictwo C.H. Beck, 2014), 109 . 
which a benefit is provided for that legal person. After all, a will cannot be witnessed by a person for whom the will envisages a benefit. However, it is not irrelevant that not every act of a natural person forming part of the governing body of a legal person can and should be regarded as an act of the legal person. If a natural person who is a member of the governing body of a legal entity is a witness to the will because he has been invited by the testator to act as such, experience shows that, as a rule, this person cannot be regarded as acting in the capacity of the body of such a legal person within the scope of competence (rather theoretically) but as a "private person." Witnessing a will does not fall within the scope of conduct designated for the governing body of a legal person. However, if the testator designated a specific natural person to be officer of the governing body of a legal person (a rare case), then Article $957 \S 1$ sentence $1 \mathrm{CC}$ would apply in connection with Article $38 \mathrm{CC}$. The participation of the governing body of a legal person in drawing up a will would then be that of the legal person itself, which, at the will of the testator, would benefit from the disposition of will, but which is not permitted under Article $957 \S 1$ sentence 1 CC used by analogy.

The view that a member of the governing body of a legal person cannot witness a will in which the benefit for this legal person is reserved for this legal person is presented quite widely in the literature of civil law, most often with reference to the theory of governing bodies binding under Polish law (Article $38 \mathrm{CC}$ ), the application of which may lead to the conclusion that the action of a body of a legal person when drawing up a will is in fact an action of the legal person itself, and thus gives the status of a witness to an entity which is to benefit from the will disposition. ${ }^{13}$ For example, Elżbieta Skowrońska-Bocian argued that: "A natural person who is the governing body of a legal person cannot be a witness to a will if that legal person obtains a benefit under the testamentary disposition. A legal person as referred to in Article 38 has to act through its governing bodies. The witnessing role of a natural person as the governing body of a legal person (forming part of the governing body of a legal person) means that the witness is in fact the legal person, that is to say the entity for which a benefit is foreseen in the will." 14 However, as already mentioned, the concept of witness should be applied only to natural persons.

\footnotetext{
${ }^{13}$ See for example PaZdAn, "Komentarz do art. 957 k.c.," 864; J. IGNACZEwSKi, Prawo spadkowe. Art. 922-1088. Komentarz (Warszawa: Wydawnictwo C.H. Beck, 2004), 161; Kremis, "Komentarz do art. 957 k.c.," 1631-32; E. NIEZBECKA, "Komentarz do art. 957 k.c.," in Spadki, ed. A. Kidyba, vol. 4 of Kodeks cywilny. Komentarz, LEX 2015, item 3.

${ }^{14}$ See also E. SKowrońSKA-Bocian, Komentarz do kodeksu cywilnego. Księga czwarta. Spadki (Warszawa: Wydawnictwo Prawnicze, 2001), 127.
} 
The conclusion that an organ of a legal person cannot witness a will which provides for a benefit to that person must be reached through different reasoning, namely by analogy to Article $957 \S 1$ sentence 2 CC. Due to structural links between the legal person and its governing bodies, it is not possible to accept that these bodies (natural persons forming part of the body of a legal person) meet the criteria of objectivity and impartiality required for a witness. Inability to witness should also be extended to persons remaining with the office holders of the governing bodies of legal persons in a relationship referred to in Article $957 \S 1$ sentence $2 \mathrm{CC}$. The reasons why a relative who receives a benefit in a will is incapable of witnessing are very similar to the reasons excluding a relative who is a member of the governing body of a legal person or a person if a benefit is provided for him or her in the will.

The principle of interpretation of legal regulations expressed by the Latin maxim exceptiones non sunt extendende does not speak against such an analogy. Only on the face of it would seem so if we takes into account that the provision of Article $957 \mathrm{CC}$ provides for exceptions to the admissibility of being a witness to the will. Values underlying the norm by virtue of Article $957 \mathrm{CC}$ are more important and justify the use of analogy (ubi eadem legis ratio ibi eadem legis dispositio). The exceptiones non sunt extendende rule must give way. In this context, it is worth noting that the Supreme Court's jurisprudence assumes that a third party recording the contents of an oral will should meet the criteria of objectivity, just like a witness. This person is therefore subject to an appropriate exemption from this under the conditions laid down for the exclusion of a testamentary witness. The term "third party" used in Article $952 \S 2$ CC does not include persons interested in the content of dispositions of the testator, which includes persons mentioned in Article 957 \& $1 \mathrm{CC}$, which applies by analogy. ${ }^{15}$ Therefore, the mother and spouse of the heir who was made eligible to inherit by oral will, as well as the testamentary heir, are not third parties within the meaning of Article 952 \& 2 CC.

Fryderyk Zoll notes that it is not acceptable to justify the view that the governing body of a legal person cannot be a witness to a will in which

\footnotetext{
${ }^{15}$ See the Decision of the Supreme Court of 13 May 1999, file ref. no. III CKN 231/98, TSO of 1999, no. 12, item 221; Decision of the Supreme Court of 14 July 2005, file ref. no. III CK 688/04, LEX no. 380963; Resolution of the panel of 7 judges of the Supreme Court of 23 November 2001, file. ref. no. III CZP 54/01, OSNC 2002, nos. 7-8, item 84; Decision of the Supreme Court of 10 May 2002, file ref. no. IV CKN 1044/00, OSNC 2003, nos. 7-8, item 107; Decision of the Supreme Court of 11 March 2011, file ref. no. II CSK 379/10, LEX no. 784916.
} 
a benefit is stipulated for that legal person under Article $38 \mathrm{CC}$. It cannot be inferred from the legal norm providing that a legal person acts through its bodies that any action taken by a natural person that is part of a body of the legal person should be considered as an action by the legal person. This applies only in cases where the person acts as the governing body of a legal person. In such a capacity, her or she would have to be summoned to witness the will (or to declare to be in such a capacity) for us to be able to accord the argument under Article $38 \mathrm{CC}$ any significance. In Zoll's opinion, if such a person does not play such a role, then the recognition that Article $957 \S 1 \mathrm{CC}$ applies to them would require different reasoning, that is the application by analogy with Article $957 \S 1$ sentence 2 CC, namely a provision which delimits the circle of close persons in relation to the person who is granted a benefit. The question whether such analogy would be acceptable in this case must be left open. However, this possibility should not be ruled out across the boeard. As Zoll notes further on, in 1964 the legislator could not have foreseen the current development of economic life, the prevalence of individual entrepreneurship, and the multitude of forms of conducting business. The reasons justifying the exclusion of relatives from witnessing are very similar to those which would justify the exclusion of a person forming part of the governing body of a legal person. The application of analogy could be hampered by the fact that the rules providing for the exclusion of certain persons from the ability to witness are exceptional. However, the principle banning analogy derived from a special provision should be approached at least with caution. Determination of the exceptionality of a provision is always relative and thus becomes a relatively arbitrary tool for legal argumentation. Therefore, this possibility should not be rejected in advance, seeing the danger that the principle of legal certainty may be breached. This is a serious argument in the case of formal criteria of a will. The testator should be confident that they will make a valid will the rules are observed. Flexible methods of interpreting the rules on the ability to witness could easily obliterate this effect.

Katarzyna Duszyńska-Misarko and Paweł Księżak, ${ }^{16}$ who note that some legal scientists recognize-with reference to Article $38 \mathrm{CC}$ - that a witness to a will may not be a natural person who is the governing body of a legal person as long as the benefit under the will is reserved for, argue however, that this is difficult to defend in terms of the structure. In their opinion, "as it seems, certain declarations or events—not only under Article $957 \mathrm{CC}$-can

\footnotetext{
${ }^{16}$ DusZYŃSKA-MisARKo and KsiĘżAK, Glosa, 1731-32, 1734.
} 
be witnessed by a person acting simply on his own behalf, in his own name. In all fairness, it not possible to assume that specific natural persons (members of the management board) act as witnesses as office holders of the governing body of a legal person, in other words, the legal person itself «acts» or actually «is a witness». As it seems, there is no possibility of being a witness for someone, in someone's name or on someone's account. A legal person may not be a witness «through its governing bodies». This does not mean, however, that the extension of the prohibitions under Article 957 \& $1 \mathrm{CC}$ to members of legal person bodies is erroneous, but it requires additional justification. The mere content of Article $38 \mathrm{CC}$ is not sufficient and it becomes quite essential to apply Article $957 \mathrm{CC}$ due to the ratio legis of this provision." These authors aptly conclude that "the prohibition under Article 957 CC should be applied to officer holders of executive authorities of local government units. And if an oral will is made in favour of the gmina, the will may not be witnessed by the wójt, burmistrz or prezydent, ${ }^{17}$ and if an oral will is made in favour of a powiat, the starost of the powiat cannot be such a witness. ${ }^{18}$ In the case of the State Treasury, the head of the organisational unit that is to benefit from a will may not witness (for example if the State Treasury-Primary School No. 1 in Łódź were to succeed, the director of that institution cannot witness) if such a unit has not been identified, only the Minister of the State Treasury would not be allowed to act as a witness." We can only add that in the case of a will benefiting a voivodeship, the voivodeship governor [marszatek województwa-Translator's note] cannot be such a witness. ${ }^{19}$

The Supreme Court admits that a different assessment should be made only if a person authorised to make statements acted as a witness (a member or members of the governing body, an attorney, or a commercial proxy). In

\footnotetext{
${ }^{17}$ Pursuant to Article 26 para. 1 (in connection with Article 11a para. 3) of the Act of 8 March 1990 on the gmina local government (Journal of Laws of 2017, item 1875, as amended), the executive body of a gmina is wójt (burmistrz, prezydent) [the latter two are heads of a town or city, respectively - Translator's note]).

${ }^{18}$ Pursuant to Article 24 paras. 1 and 2 of Act of 5 June 1998 on powiat local government (Journal of Laws, item 1868, as amended), the powiat management board is its executive body. The powiat management board comprises a starost as its presiding officer, a deputy starost and the other members.

${ }^{19}$ Pursuant to Article 31 paragraphs 1 and 2 of the Act of June 5, 1998 on voivodeship government (Journal of Laws of 2017, item 2096, as amended), the management board of a voivodeship is its executive body. The voivodeships management board, comprising 5 people, includes a voivodeships governor [marszałek] as its presiding officer, one or two deputy governors, and the other members.
} 
the Court's view, although in such a case the legal person would not be able to witness a will, as it is not permitted, it would be permissible to apply Article 957 \& 1 CC by analogy. Here, I see two errors in the Supreme Court's reasoning. First, it is irrelevant whether or not a witness to a will appears as a person authorised to make declarations of will on behalf of a legal person, that is to say, as an office holder in a governing body. Being a witnesses to a will, it does not make any declaration of will for a legal person, nor is it - as the governing body of a legal person-a recipient of the declaration made by the testator. The testator's declaration of will is a statement that has no recipient. Secondly, there is no juridical justification for excluding from the circle of testamentary witnesses a person who is the attorney of a legal person or the commercial proxy of a legal person who is an entrepreneur. After all, an authorised agent, just like a commercial proxy, is a third party to the legal entity he represents. His declarations of will have a direct effect in the legal sphere of the principal provided that they have been submitted within the limits of the authorisation and the remaining conditions for the admissibility of a legal act through an attorney (commercial proxy) are met.

The Supreme Court should be criticized as being arbitrary in saying: "Similarly, in fact, a member of a corporate legal entity which is to benefit from a will can stand witness to it. However, a situation in which the sole or majority shareholder in a limited liability company were such a witness should be viewed differently." In my opinion, no distinction should be made regarding a shareholder in a limited liability company (joint-stock company) acting as a witness to the will in which the testator makes the company eligible to inherit depending whether the company is based on sole proprietorship or whether it has two or more shareholders. Similarly, it should be irrelevant whether the shareholder has a majority or a minority. A company as a legal person is always an entity separate from its shareholders who are subject to civil law. The company has its own assets and is responsible for its own obligations. The structure of a legal entity as a civil law entity permits, on the one hand, concentration of capital and, on the other, it reduces the risk associated with functioning in civil law transactions by limiting liability for debts by natural persons who are participants (shareholders) in the legal entity. ${ }^{20} \mathrm{~A}$ shareholder of a company is not responsible for the company's

\footnotetext{
${ }^{20}$ See E. NiEzBECKA, "Część I. Część ogólna prawa cywilnego. Rozdział VII. Podmioty prawa cywilnego," in Zarys prawa cywilnego, by T.A. FILIPIAK et al. (Lublin: Oficyna Wydawnicza Verba, 2006), 128.
} 
liabilities even if he is its sole shareholder and, as it is commonly felt, whether he is treated in the economic sense as the "owner of the company" or finally treats himself in this way.

Zoll $^{21}$ rightly argues that the question arises as to whether a shareholder of a capital company (or even a partnership as the structure envisaged by the Commercial Companies Code already clearly separates a partnership from its partner) may witness a will offering a benefit for that partnership. In his opinion, two types of solutions are possible here. It can be concluded that a similar conflict of interest exists here as in the case of a person forming part of the governing body of a legal person for whom a benefit is provided in a will. The second option may be to use an interpretation using the category of benefits. Predicting benefits for a limited liability company (this will be clearly visible in the case of sole proprietorship), when a shareholder acts as a witness to a will, means predicting an indirect benefit for himself. In this way, the value of his share increases. According to Zoll, the construal of benefits in the light Article 957 \& 1 CC should also encompass such cases. Increasing the company's assets has a direct impact on the value of the shareholder's assets through participation and does not meet the requirement of impartiality and lack of personal interest in the content of the will, which is essential for being a testamentary witness. ${ }^{22}$

Zoll's viewpoint—shared by Duszyńska-Misarko and Księżak ${ }^{23}$-are critically assessed by Konrad Osajda ${ }^{24}$ in the literature, a stance which we cannot endorse. Osajda considers that Zoll's position disregards the separate legal personality of the legal person and its associates, having an excessively general character. Although the benefit provided for in a last will for a company constitutes in fact an indirect benefit for the shareholder himself, it is not included in his assets (or at most may increase the value of the shares in the legal person at his disposal). In addition, it is an indirect benefit only with respect to legal entities which bring profits to their members (intended to carry out activities for the benefit of its members). In his opinion, de lege lata it cannot be assumed that both members of the bodies of legal entities and members of the legal entities themselves cannot witness

\footnotetext{
${ }^{21}$ WóJCIK and ZoLl, Rozdziat IV. Testament, 398.

${ }^{22}$ For a different but incorrect interpretation, see K. OsAJDA, "Komentarz do art. 957 k.c.," in Spadki, edited by K. Osajda, vol. 3 of Kodeks cywilny. Komentarz (Warszawa: Wydawnictwo C.H. Beck, 2013), 422.

${ }^{23}$ DuSZYŃSKA-MiSARKO and KsIĘŻAK, Glosa, 1733.

${ }^{24}$ See OSAJDA, "Komentarz do art. 957 k.c.," 422.
} 
a will in which a benefit is reserved for that legal person. ${ }^{25}$ However, due to the controversy outlined in the doctrine, Osajda strongly advises against the participation of such individuals in testing.

I am not convinced by the position of Kondrad Osajda who believes that de lege ferenda-in its purpose-oriented aspect-the possibility of extending the disposition of Article $957 \mathrm{CC}$ should be extended to those situations, because the members of the governing body of a legal entity, and probably even more so the members of that legal entity itself, may be interested that the entity managed or established by them obtains a financial benefit from the testator as they will indirectly obtain this benefit. I am of the opinion that if an oral will (or a nuncupative will) envisaged a benefit, for instance, for Alfa Sp. z o.o., none of the shareholders in the company could be a witness in such a will (it should be emphasized once again that it is irrelevant whether the company is sole proprietorship or whether it has more shareholders and whether the shareholder-the witness has majority or minority shares in it), as well as none of the members of the management board. If, despite the fact that the company's share capital does not exceed PLN 500,000 and there are no more than twenty-five shareholders, a supervisory board or an audit committee was established, ${ }^{26}$ then none of its members could act as witness either. It is immaterial whether the witness is an office holder of the governing body (usually the management board), constituting (e.g. the shareholders' meeting of spótka $z$ o.o. or the general meeting of spótka akcyjna), or the supervisory body (supervisory board, audit committee). The members (shareholders) of legal entities as well as their officers have an indirect interest in the legal entity gaining a benefit (this benefit obtained by the legal entity may improve their situation in various ways); further, an increase in the assets of that legal entity directly affects the value of the shareholder's assets (the greater his share in the company, the greater is the increase in his assets due to the testamentary increment benefiting the legal entity). Therefore, it cannot be said that shareholders of legal entities can act as witnesses to wills because the requirements of impartiality and lack of personal interest are fulfilled in this special way as provided by the will.

\footnotetext{
${ }^{25}$ Ibid.

${ }^{26}$ Pursuant to Article $213 \S 1$ of the Commercial Companies Code, the articles of association may establish a supervisory board or an audit committee or both. In companies where the share capital exceeds 500,000 PLN and there are more than twenty-five shareholders, a supervisory board or an audit committee should be established ( $\S 2$ ). If a supervisory board or an audit committee is established, the articles of association may exclude or limit the individual control of shareholders $(\S 3)$.
} 
I agree with Duszyńska-Misarko and Księżak ${ }^{27}$ that the exception in this respect could be made for local government units and the State Treasury. This is simply results from the specific nature of these legal entities. As these authors point out, a distinct approach to units of local government mainly derives from the fact that they are in fact local government communities of people inhabiting a particular area (gmina residents constitute a local government community by the power of law; powiat residents constitute a local government community by the power of law; voivodeship residents constitute a regional government community by the operation of law). Theoretically, if the testator wanted to make an oral will for the benefit of a gmina, for example, no gmina inhabitant would be able to witness the will as a member of the gmina. In the opinion of these authors, such a conclusion is obviously too far-reaching, especially since the benefit obtained by the gmina does not constitute a benefit for a member of the local government community of that gmina in the same sense as in the case of shareholders of corporate legal entities. In my opinion, such an interpretation is rational, justified in life, and thus practical, and does not contradict the ratio of the norm from Article $957 \mathrm{CC}$.

Similarly, in the case of the State Treasury (which is the State itself with an inherent attribute of legal personality, ${ }^{28}$ appearing in transactions under civil law within the its dominium $^{29}$ ), the indirect benefit acquired by each member of the State community as individuals residing in the territory of Poland would call for adoption of an absurd idea that none of the citizens of the Republic of Poland could witness a will benefiting the State Treasury as the heir to the whole or part of the inheritance. In the same vein, also members of the Catholic Church (or any other church) may witness a will in which there is a benefit for the Catholic Church (or any other church) or its organisational structures with legal personality, such as dioceses or parishes. ${ }^{30}$

\footnotetext{
${ }^{27}$ DuSZYŃSKA-MiSARKO and KSIĘŻAK, Glosa, 1733-34.

${ }^{28}$ See: NiEZBECKA, Część I. Część ogólna prawa cywilnego, 136.

${ }^{29}$ The sphere of dominium includes rights and obligations arising from legal relations between the State and other entities, based on the principle of equivalence of entities and autonomy of the will of the parties. The State may act as a participant of transactions under civil law, as a subject of ownership and other property rights. In the latter case, it acts as the State Treasuryan autonomous civil law entity with legal personality, see for example KAWAŁKO and WITCZAK, Rozdziat IV. Podmioty, 113.

${ }^{30}$ In accordance with Article 4 of the Concordat between the Holy See and the Republic of Poland, signed in Warszawa on 28 July 1993 (Journal of Laws of 1998, No. 51, item 318): "1. The Republic of Poland recognises the legal status of the Catholic Church. 2. The Republic of Poland
} 
In the case at hand, which was settled by the Supreme Court, the oral will in which a benefit was provided by making the Gmina of U. the only successor was witnessed the sołtys and his spouse. The Supreme Court is right in stating, with reference to Article $36 \S 1$ the Act of 8 March 1990 on gmina local government, ${ }^{31}$ that the soltys is not a body of gmina but the executive body of a sotectwo, which in turn is auxiliary to the former. Pursuant to Article 5 para. 1 of the Act, the gmina may establish the following auxiliary territorial units: sołectwo [village circuit], dzielnica [district of a village], osiedle [housing estate in a village-Translator's notes] and others. A town located within the gmina may also function as an auxiliary unit. Auxiliary units can be created by the rada gminy [municipal council], by way of a resolution, after consultation with the inhabitants or on their own initiative. The rules for establishing, merging, dividing and suppressing auxiliary units are laid down in the gmina statute (Article 5 paras. 2-3). Therefore the assessment presented in the case at hand is correct in that the sołtys was permitted to witness the making of the will.

The same could be said in the situation where a will benefiting Gmina of $\mathrm{X}$ is witnessed by natural persons who are members of bodies of separate entities established under civil law and affiliated with the gmina, for example if a will is witnessed by a natural person having membership in:

a) the governing body of an inter-municipal union established, among others, by Gmina of $\mathrm{X}$ (in order to jointly perform public tasks and for joint service referred to in Article 10a of the Act on gmina local government; gminas may establish inter-municipal unions that acquire legal personality on the date when the statute is announced, specifying, among others, the governing bodies of the union, their structure, scope and mode of operation -Articles 64-65, Article 67 para. 2 point 4 and para. $2 b$

b) the governing body of an association established by, among others, Gmina of X (in order to promote the ideas of local self-government and to safeguard common interests, gminas may create associations, also together with powiats and voivodeships. The organization, tasks and mode of operation of the association are defined in its statute. The provisions of the law on

also recognises the legal status of all ecclesiastical institutions, land and personnel, who are deemed so according to the norms of canon law. The Church authorities shall give due notice of these to the appropriate organs of the State. 3. At the request of the Church authorities, other ecclesiastical institutions may also acquire legal status, in accordance with Polish law."

${ }^{31}$ Pursuant to Article 36 para. 1 of the Act on gmina local government, the legislative body of the solectwo [sub-unit of the gmina-Translator's note] is the village assembly, and its executive body is the sottys, who is supported by the rada sotecka [village council]. 
associations apply respectively to municipal associations, except that at least three founders are required to establish an association (Article 84, paras. 1-3 of the Act on gmina local government)

c) the governing body of a municipal legal entity established by Gmina of $\mathrm{X}$ (in order to perform their tasks, gminas may establish organizational units, including municipal legal entities; these can conduct business activity going beyond the tasks of public utility only in cases specified in a separate actArticle 9 of the Act on gmina local government and Article 2, Article 9 of the Act of 20 December 1996 on municipal management ${ }^{32}$ ).

No breach of Article $957 \mathrm{CC}$ will occur if the witnesses of a will in which a benefit for Gmina of $\mathrm{X}$ is provided for are Gmina employees in $\mathrm{X}$ (not being members of the gmina governing body). However, if the making of a will is witnessed by the wójt of Gmina of $\mathrm{X}$-who is its executive bodyin my opinion Article $957 \mathrm{CC}$ will be violated (unless there are three other witnesses who are not prohibited to witness ${ }^{33}$ ).

Finally, we do not know what the Supreme Court had in mind in its ruling when stating that a member of the governing body of a legal person can in principle [emphasis-G.W.] witness the making of a will in which there is a benefit to this entity. Similarly, in principle [emphasis-G.W.], the making of a will may be witnessed by a member of a corporate legal entity for whom the will envisages a benefit. It was not indicated when (in what situations and under what criteria, circumstances, etc.) this principle would not apply, and as a result the indicated categories of entities would not be able to be testamentary witnesses.

Another argument is therefore more correct, namely that a member of the governing body of a legal entity cannot in principle witness the making of a will in which a benefit is envisaged to it. Similarly, in principle, a member (shareholder) of a corporate legal entity for which a benefit is provided in

\footnotetext{
${ }^{32}$ Journal of Laws of 2017, item 827.

${ }^{33}$ Just like Michał Niedośpiał, I believe that, among other things, using the argument of argumentum a maiori ad minus, it must be concluded that since the absolute inability of an excess witness does not entail invalidity of a will, the presence of a witness or an incapable witness cannot invalidate all or part of the will. The presence of the necessary witnesses provided for in the law is a sufficient guarantee of the validity of the will and proper succession, see M. NIEDOŚPIAL, "Niezdolność świadków sporządzenia testamentu-glosa-III CZP 22/02," Monitor Prawniczy 2 (2004): 92-94. A different position can be found in PAZDAN, "Komentarz do art. 957 k.c.," 865, who believes that the incapacity of an excess witness caused by the reason under Article 957 \& $1 \mathrm{CC}$ will entail the consequences specified in Article $957 \S 2$ CC), i.e. invalidity of that part of the will (Article 957 para. 2, sentence 1 CC), which is typical, or the invalidity of the entire will (Article 957 $\S 2$, sentence 2), which is an exception to the rule (Article $957 \S 2$, sentence $1 \mathrm{CC}$ ).
} 
a will may witness it. In doing so, account is taken of the fact that there are legal entities (with exceptions though) whose members cannot be validly assumed to act as witnesses to a will with a benefit for those entities. In the case of such members their benefit is "much too indirect."

Finally, we should address another issue, namely whether the breach of Article $948 \S 1$ in relation to Article $962 \mathrm{CC}$ alleged in the complaint in cassation should have been considered correct, contrary to the position presented by the Supreme Court. In this respect, the Supreme Court stated that this allegation is intended to challenge the Regional Court's position regarding the fact that the testator's declaration of will was made without stipulating a condition. As further stated by the Supreme Court: "Also in this case, the correct factual findings of the courts of both instances are being challenged. The oral will, made on June 13, 2010, makes reference to the will of May 2004, which-made with a condition stipulated-was invalid. However, while the will benefiting the Foundation in S. was indeed conditional, the will of June 13, 2010, in which Gmina of U. was named as the successor, was made when the testator was already in the care of the Gmina."

In my opinion, the oral will of June 13, 2010 was not invalid due to its conditionality (nor was the one of May 2004 invalid). If anything, the appointment of an heir made in the will, which in itself does not imply its invalidity at all. The testator's statement: "I devise and bequeath all my estate to Gmina of U. in exchange for my care and maintenance in the nursery home," as accurately accepted by the Courts of the first and second instance and approved by the Supreme Court, should be considered as the testator's expression of gratitude for placing her in the centre in a situation of her serious illness, and not as a condition within the meaning of Article 89 CC. In this way, as it were, the testator wanted to justify her decision to make this entity her heir. Furthermore, even if the reservation contained in the 2004 will and in the one of 2010 were to be regarded as a condition, that condition was fulfilled (or not) on the day when the succession was opened and therefore could not invalidate the will. The ban on conditional or time-bound appointment of an heir in a will stipulated in Article $962 \mathrm{CC}$ does not apply if the fulfilment (positive condition) or non-fulfilment (negative condition) or the expiry of the time limit took place before the succession was opened (Article 962 the third sentence CC). As noted in the literature, such circumstances causes that the naming of an heir at the time of the opening of the succession is no longer conditional or time-bound, so that there can be no 
breach of any prohibition. ${ }^{34}$ Article $962 \mathrm{CC}$ provides that stipulation of a condition or a time limit made when naming a testamentary heir is considered null and void. However, if it transpires from the will or from the circumstances that without such a condition the heir would not be appointed, the appointment of the heir is null and void. These provisions do not apply if the fulfilment or non-fulfilment of the condition or the arrival of the deadline took place before the opening of the succession.

\section{CONCLUSION}

In summary, the initial view of the Supreme Court cannot be upheld. We can only hope that in the future the Supreme Court will abandon this direction in its interpretation of Article 957 or the Civil Code, which will ensure full objectivity, required of witnesses to a will, and this is precisely to guarantee reliability and compliance of the performance of the last will ex post. It is appropriate to say that a last will providing for a benefit for a legal entity cannot, in principle, be witnessed by either an officer of such an entity or none of the members (shareholders) of a corporate legal entity.

\section{BIBLIOGRAPHY}

\section{SOURCES OF LAW}

Concordat between the Holy See and the Republic of Poland, signed in Warsaw on 28 July 1993. Journal of Laws of 1998, No. 51, item 318.

Ustawa z dnia 23 kwietnia 1964 r. Kodeks cywilny [Act of 23 April 1964 - The Civil Code]. Journal of Laws of 2017, item 459, items 459, 933, 1132.

Ustawa z dnia 8 marca 1990 r. o samorządzie gminnym [Act of 8 March 1990 on gmina local government]. Journal of Laws of 2017, item 1875, as amended.

Ustawa z dnia 20 grudnia 1996 r. o gospodarce komunalnej [Act of 20 December 1996 on municipal management]. Journal of Laws of 2017, item 827.

Ustawa z dnia 5 czerwca 1998 r. o samorządzie powiatowym [Act of 5 June 1998 on powiat local government]. Journal of Laws of 2017, item 1868, as amended.

Ustawa z dnia 5 czerwca 1998 r. o samorządzie województwa [The Act of 5 June 1998 on voivodeship local government]. Journal of Laws of 2017, item 2096.

\footnotetext{
${ }^{34}$ See for example E. NiEZBECKA, "Komentarz do art. 962," in Kodeks cywilny. Komentarz, vol. IV, point 3 .
} 


\section{Case Law}

Decision of the Supreme Court of 13 May 1999, file ref. no. III CKN 231/98, OSP of 1999, No. 12, item 221.

Decision of the Supreme Court of 10 May 2002, file ref. no. IV CKN 1044/00, OSNC of 2003, nos. 7-8, item 107.

Decision of the Supreme Court of 14 July 2005, file ref. no. III CK 688/04, LEX no. 380963.

Decision of the Supreme Court of 11 March 2011, file ref. no. III CKN 379/10, LEX no. 784916.

Decision of the Supreme Court of 16 October 2014, file ref. no. III CKN 301/13, LEX no. 1598693.

Resolution of the panel of 7 judges of the Supreme Court of 23 November 2001, file ref. no. III CZP 54/01, OSNC of 2002, nos. 7-8, item 84.

\section{LITERATURE}

BŁahutA, Franciszek. "Komentarz do art. 957 k.c.” In Kodeks cywilny. Komentarz, 3: 1884. Warszawa: Wydawnictwo Prawnicze, 1972.

Duszyńska-Misarko, Katarzyna and Paweł KsiężAK. Glosa do postanowienia SN z dnia 16 października 2014 r., III CSK 301/13. OSP of 2015, no. 12, item 117, pp. 1730-35.

Haberko, Joanna. "Komentarz do art. 957 k.c." In Kodeks cywilny. Tom II. Komentarz do art. 450-1088, edited by Maciej Gutowski. Warszawa: Wydawnictwo C.H. Beck 2016, Legalis.

IgnACZEwSKI, Jacek. Prawo spadkowe. Art. 922-1088. Komentarz. Warszawa: Wydawnictwo C.H. Beck, 2004.

KawaŁko, Agnieszka, and Hanna Witczak. "Rozdział IV. Podmioty prawa cywilnego, § 13. Osoby prawne.” In Prawo cywilne-część ogólna, 100-117. Warszawa: Wydawnictwo C.H. Beck, 2014.

KREMIS, Józef. "Komentarz do art. 957 k.c.” In Kodeks cywilny. Komentarz, edited by Edward Gniewek and Piotr Machnikowski, 1630-32. Warszawa: Wydawnictwo C.H. Beck, 2013.

NIEdoŚPIAE, Michał. "Glosa do postanowienia SN z dnia 16 października 2014 r., III CSK 301/13." Palestra 4 (2017): 100-108.

NiEdoŚPIAŁ, Michał. "Niezdolność świadków sporządzenia testamentu—glosa—III CZP 22/02." Monitor Prawniczy 2 (2004): 92-94.

NiEZBeCKA, Elżbieta. "Część I. Część ogólna prawa cywilnego. Rozdział VII. Podmioty prawa cywilnego." In Zarys prawa cywilnego, by Teresa A. FILIPIAK, Jan MOJAK, Mirosław NAZAR et al., 115-45. Lublin: Oficyna Wydawnicza Verba, 2006.

NiEZBECKA, Elżbieta. “Komentarz do art. 957 k.c.” In Spadki, edited by Andrzej Kidyba. Vol. 4 of Kodeks cywilny. Komentarz. LEX 2015.

NiEZBECKA, Elżbieta. “Komentarz do art. 962 k.c.” In Spadki, edited by Andrzej Kidyba. Vol. 4 of Kodeks cywilny. Komentarz. LEX 2015.

OSAJDA, Konrad. "Komentarz do art. 957 k.c." In Spadki, edited by Konrad Osajda. Vol. 3 of Kodeks cywilny. Komentarz, 418-28. Warszawa: Wydawnictwo C.H. Beck, 2013.

PazDAn, Maksymilian. "Komentarz do art. 957 k.c.” In Kodeks cywilny. Tom II. Komentarz. Art. 455-1088. Przepisy wprowadzajace, edited by Krzysztof Pietrzykowski, 864-65. Warszawa: Wydawnictwo C.H. Beck, 2013. 
SKOWROŃSKA-BOCIAN, Elżbieta. Komentarz do kodeksu cywilnego. Ksiegga czwarta. Spadki. Warszawa: Wydawnictwo Prawnicze, 2001.

STECKI, Leopold. "Komentarz do art. 957 k.c." In Kodeks cywilny z komentarzem, edited by Jan Winiarz, 856-57. Warszawa: Wydawnictwo Prawnicze, 1980.

WóJciK, Sylwester, and Fryderyk ZoLl. "Rozdział IV. Testament." In Prawo Spadkowe, edited by B. Kordasiewicz. Vol. 10 of System Prawa Prywatnego, 331-419. Warszawa: Wydawnictwo C.H. Beck, 2015.

\section{A GLOSS TO THE DECISION OF THE SUPREME COURT OF 16 OCTOBER 2014, FILE REF. NO. III CSK 301/13}

\section{Summary}

The gloss addresses the decision of 16 October 2014, III CSK 301/13, in which the Supreme Court adopted the position that a member of the governing body of a legal entity may, in principle, be a witness to making a testament in which a benefit is provided for that legal person. Similarly, in the Supreme Court's opinion, a witness to the making of a will may, in principle, be a member of a corporate legal person for which a benefit is provided in that will. The author offers a critical assessment of that position. He considers as appropriate the view according to which a last will in which a benefit is envisaged for a legal person cannot, in principle, be witnessed by either an officer of such a legal entity, or by any member (shareholder) of a corporate legal person.

Key words: last will and testament; witness; legal entity; governing body of a legal person; member (shareholder) of a corporate legal person.

Translated by Tomasz Patkowski

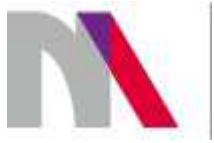

The preparation of the English version of Roczniki Nauk Prawnych (Annals of Iuridical Sciences) and its publication in electronic databases was financed under contract no. 836/PDUN/2018 from the resources of the Minister of Science and Higher Education for the popularization of science. 